\title{
Innovative Chemistry Learning Model to Improve Argumentation Skills and Self-Efficacy
}

\author{
Farah Erika $^{1)}$, Binar Kurnia Prahani ${ }^{2)}$ \\ ${ }^{1}$ (Department of Chemistry Education, Mulawarman University, Indonesia) \\ ${ }_{2}^{2}$ (Department of Science Education, Sunan Ampel State Islamic University of Surabaya, Indonesia)
}

\begin{abstract}
Argumentation skills was needed to address the problems related to scientific issues that occur in every aspect of the lives of today's society, which requires individuals and communities to have the ability to think, make decisions, ethical considerations and assessing a claim that appears either through the press or media the other based on the evidence that is valid and reliable. It takes self-efficacy in the implementation of argumentation skills. Self-efficacy is important because it can affect cognition, motivation, affective processes and ultimately the behavior of individuals. Innovation chemistry learning was need to master the skills argue and self-efficacy. Innovations have been made by researchers to have developed an innovative chemistry learning model that can integrate argumentation skills and self-efficacy. Innovative chemistry e learning model that has been developed is expected to be an alternative solution to improve the argumentation skills and selfefficacy chemistry teacher students.
\end{abstract}

Keywords: Argumentation skills, chemistry innovative learning model, self-efficacy

\section{Introduction}

Agenda of the $21^{\text {st }}$ century recognizes that education is fundamental to achieving sustainable development goals. Education has been in the implementation of sustainable development as an effective instrument for communication, information, awareness, learning and mobilizing the masses/communities, and to mobilize the nation to a future life that grows more sustainable (more sustainably developed) ${ }^{[1,2]}$. Students and graduates should have been able to communicate, creativity, critical thinking, and collaboration ${ }^{[3]}$. Partnership for $21^{\text {st }}$ Century Skills has also stressed that in order to succeed in college, career and life, in addition to mastery of academic content, also needed skills such as communication skills, technology literacy, collaboration and critical thinking skills. Critical thinking skills that have been referring to the $21^{\text {st }}$ century skills are the skills to analyze and evaluate the evidence/data, arguments, claims and beliefs ${ }^{[4]}$.The ability to argue has become one of the competencies needed because of the argumentation can develop critical thinking skills ${ }^{[5]}$. Osborne et al ${ }^{[6]}$ have found that the ability to argue is needed to address issues related to scientific issues that occur in every aspect of the lives of today's society, which requires individuals and communities to have the ability to think, make decisions, ethical considerations and assessing a claim that arise both through the press and other media based on the evidence that is valid and reliable. Besides argumentation skills also been able to improve the performance and results of student science learning ${ }^{[7,8]}$. The argumentation skills is the discourse of behavioral science is very important in the process of science and should be taught and learned in science classes as part of the inquiry and scientific literacy ${ }^{[9-11]}$. The importance of argumentation skills in science education have also been reported in many studies ${ }^{[9,12-14]}$.

The results of PISA have concluded that students Indonesia has no scientific reasoning ability and ability to construct explanations based on evidence and arguments using critical analysis ${ }^{[15,16]}$. Low reasoning ability of students allegedly linked to the learning process that has not been fully argumentation skills. Driver et al. ${ }^{[17]}$ have identified one of the key obstacles to learning in the classroom argue is the lack of pedagogical skills of teachers in organizing argumentative discourse in the classroom and this can have consequences lack of opportunities given to students to practice argue in class. Some research has shown that teachers do not understand the basics of epistemological arguments and they have the knowledge and pedagogical skills were limited, especially in designing learning activities to support the effective engagement of argumentation skills for their students ${ }^{[18-21]}$. Several previous studies have also shown they lack the ability to argumentation skills teacher student ${ }^{[22-27]}$. Learning that has involved the argumentation skills is a challenge for the student, the student must have fought in this process as well as their confidence in their belief ${ }^{[28]}$. Belief in the entire capabilities includes confidence, adaptability, cognitive capacity, intelligence and capacity to act in stressful situations. Self-efficacy is needed in the implementation of arguing skills. Self-efficacy is important because it can affect cognition, motivation, affective processes and in the end that person's behavior ${ }^{[21,29,30]}$. Jerald ${ }^{[31]}$ has revealed that teachers who have high self-efficacy tend to have shown a higher level in terms of planning and organizing, more open to new ideas, and more willing to experiment with new methods in order to meet the needs of students. Several previous studies have supported the importance of the concept of self-efficacy in 
relation to the performance of students, academic achievement, attitude towards the chemistry, problem solving skills and communication skills ${ }^{[21,32-35]}$. Preliminary studies in Graduate Program of Chemistry Education in Mulawarman University, has shown that in general self-efficacy chemistry student teachers to study of organic chemistry is quite. $46.82 \%$ of the students who believe they always succeed in learning organic chemistry, while $53.18 \%$ are still unsure of his ability in learning organic chemistry; they sometimes feel stressed and nervous when following study organic chemistry. It has shown the importance of self-efficacy of students in the learning of chemistry in college. Self-efficacy can have an impact not only on the diligence of students in basic chemistry lectures but also later in life for their perseverance in following the course further. Concerns about the weakness of the argumentation skills can be offset by Argument-Driven Inquiry (ADI) model. Model ADI has been widely applied to develop both the argumentation skills argue and the quality of the argument ${ }^{[36-42]}$. However, in the implementation of this ADI learning model has some weaknesses ${ }^{[43-46]}$.

Based on the above it is known that when a teacher has not had a pedagogical knowledge and skills necessary to apply the lessons learned in class-based arguments, it will have consequences the lack of opportunity given to students to practice argumentation skills. An implementation argumentation skill in learning requires teachers who understand the process of argumentation and self-efficacy beliefs about the benefits of good argumentation in science learning. However, knowledge about the strategies that can improve the use of argumentation skills, knowledge pedagogical argumentation skills and self-efficacy of teachers to teach science through argumentation is still limited ${ }^{[21]}$. Therefore, efforts to develop a model that can integrate argue skills and self-efficacy. This innovation is expected to be able to be an alternative solution to improve the argumentation skills and self-efficacy chemistry student teachers.

\section{A. Argumentation Skills}

\section{Discussion}

Argumentation is an important discourse in the process of science, and therefore must be implemented in science classes ${ }^{[10,11]}$. Scientific arguments are based around a particular claim or statement, which is justified by the conjunction with supporting evidence or data ${ }^{[47]}$. The argumentation is the reasoning strategies that are in the domain of informal reasoning and critical thinking ${ }^{[10]}$. Sampson and Clark ${ }^{[8]}$ distinguish between argumentation and arguments by using the 'argumentation' means data used by students to articulate and justify the claims or conclusions and 'argument' to describe the process as a whole. Therefore, the argumentation in scientific topics can be defined as the relationship between claims and data through a justification or evaluation of knowledge claims in evidence, either empirical or theoretical ${ }^{[9]}$. Based on the definition of the argumentation and the argument that have been described can be concluded that the argumentation is an idea or a conclusion based on reasoning and supported by evidence, while the argument is the process of reasoning in arguing. Eduran et al. ${ }^{[48]}$ have argued that the study framework of the argumentation associated with the sociocultural perspective of learning and thinking processes. The development of higher level thinking processes shaped by social media activity of language, thus the argumentation is a discourse that must be introduced to students and are taught explicitly through appropriate learning.

Argumentation theory has emerged from the need to define the logic that occurs in everyday contexts. This need has been identified for most of the topics related to the logic of the argument are based on analytical which conclusions are drawn from a premise ${ }^{[49]}$. Based argumentation learning engage learners in cognitive and social activities and processes have resulted in improved learning outcomes ${ }^{[50]}$. Moreover, the argument has involved students in meaningful learning as it allows learners to give more justification on their understanding $\left[19,{ }^{20]}\right.$. Based on cognitive view, to formulate an argument is a conceptual process to develop a conceptual understanding ${ }^{[51]}$. Students need to develop some understanding and being able to argue scientifically important. First, students have to be able to use an important conceptual structures (i.e., theories, models, and law or a combination of several concepts) and cognitive processes when reasoning about a problem. Second, students have had to know about science epistemic framework to develop and evaluate the claims. Third, students should be involved in argumentation scientific and social process of how knowledge is communicated, displayed, discussed and debated in science ${ }^{[52]}$. There is a cognitive argumentation values in science education. According to the cognitive perspective, by far the argument involves the exercise of reasoning (Kuhn, 1992 and Billig, 1996) in ${ }^{[48]}$. Externalizations by Vygotsky require a step of intra-psychological field, and rhetorical arguments, the argument between the psychological and dialogical. When children are involved in the process, and support each other in the argument of high quality, the interaction between the personal and social dimensions of increasing reflexivity, the development of knowledge, beliefs and values ${ }^{[48]}$.

A view on cognitive learning theory has focused on changing the thinking involved in learning. This theory has emphasized the mental processes that underlie the processing of new information, such as attention to the explanation, interpreting graphs, or related new concepts to prior knowledge. Because of this emphasis, cognitive theory has defined learning as a relatively enduring change in mental structures that occur as a result of the interaction of individuals with the environment ${ }^{[53]}$. The involvement of argumentation in science learning 
have can also be studied from constructivist learning theory. The essence of the idea of constructivism is active students build their knowledge of their personal experiences with others and the environment ${ }^{[53]}$. The individual constructivism has known as cognitive constructivism Piaget. Individual constructivism focus on how individuals construct knowledge in his mind. This theory supports learning by inductive approaches such as inquiry-based learning. In this method, the teacher asks the students to answer a question or a problem, formulate hypotheses, and collect data to test hypotheses, draw conclusions, and reflect on the question and their thought processes, while social constructivist theory emphasizes the social context of the rules in building knowledge. Learners divide individual perspectives with others to build a common understanding that not be done alone. Social constructivism is largely based on the work of Vygotsky. Vygotsky's theory of constructivism is also known as the theory of social culture. Vygotsky not only insists on rules that facilitate social interaction in cognitive development of learners but also consider the situation of learning in the culture of the learners. This is because the learners bring experience, values and knowledge of different social constructivists believes that each student will build knowledge that is different from the material the same instructions. Characteristics of social constructivist learning is to use realistic problems, emphasizing multiple perspectives, and help scaffolding through the nearest development zone (zone of proximal development) ${ }^{[53]}$. Vygotsky idea of proximal development zone (zone of proximal development) states that learners are helped to lead to higher levels of performance through support from friends or from the teacher. At first, what do the students depend on teachers, but increasingly independent after mastering the task of learning and gain control over the new functionality. The task of the lecturer is to provide an environment and conditions that allow students to learn to master new skills and learn new things.

Results of previous studies have revealed that the argumentation is the discourse of behavioral science is very important in the process of science and should be taught and learned in science classes as part of the inquiry and scientific literacy ${ }^{[9-11]}$. The argumentation has been can be described as a discourse where knowledge claims individually and collaboratively constructed and evaluated by empirical evidence or theoretical ${ }^{[9]}$. Argumentation is part of a behavioral decision and defends it, influencing others according to data accompanied by rationalization ${ }^{[54]}$. The decision could be the answer to a problem or a conviction finding ${ }^{[55]}$. An argumentation also means building a socio-cultural activity through the presentation, interpretation, criticism, and revisions to an argument ${ }^{[56]}$. Class content has combined science with explicit instructions argumentation can produce a high quality of students who follow those instructions, other findings have also shown that prior knowledge influences the content knowledge that is used to support student argument ${ }^{[57]}$.

\section{B. Self-Efficacy}

The theory of self-efficacy is based on Bandura's social cognitive theory. Bandura defines self-efficacy as consideration a person's ability to organize and carry out the actions necessary to achieve a particular feat. Self-efficacy is not the common belief about himself but rather specific beliefs that lead to a particular task. Self-efficacy has been can be seen as one's perception of her ability to organize and carry out actions in specific situations. Self-efficacy has been appointed to the belief in his ability to drive motivation, cognitive resources and a series of actions required to cope with the demands of the situation. According to Bandura ${ }^{[58,59]}$ selfefficacy can be obtained, modified, upgraded, or downgraded by one or a combination of four sources: mastery experiences, vicarious experiences, verbal persuasion, and affective state.

Several previous studies have examined the factors that have been able to increase self-efficacy beliefs of students and its relationship with the four sources ${ }^{[60,61]}$. The study revealed that a constructive classroom environment as Problem Based Learning (PBL) is a major contributor to increasing self-efficacy. PBL learning environment has the potential to encourage self-efficacy because students set their goal and develop a realistic plan to achieve goals ${ }^{[62]}$. Bandura's social cognitive theory assumes that the very aim (purposeful), goal-directed being, which can mainly be motivated by their belief of self-efficacy and outcome expectations (outcome expectations) derived from their actions in a particular social context. Bandura identified three key processes in the personal factors that have a significant impact on humanitarian agencies. The three key processes are (a) self-efficacy beliefs, (b) expectation of results, and (c) self-learning. Human actions are mediated largely through a process of self so that the social environmental factors influence each other, but only partially explain the behavior ${ }^{[63]}$. Socio-cognitive theory focuses on learning is the result of observing others or to observe the consequences of other people's behavior. Various things can happen in a social context one has learned by observing and imitating the behavior of others ${ }^{[53]}$. This research reveals a link between a person's self-efficacy beliefs by performing a specific task ${ }^{[21]}$. A person's self-efficacy beliefs can affect cognition, motivation, affective processes and in the end that person's behavior ${ }^{[29]}$. Collaborative processes within a learning model that provides explicit feedback to students about their performance is a source of efficacy that can promote the development of self-efficacy ${ }^{[64]}$. 


\section{Innovative Chemistry Learning Model to Improve Argumentation Skills and Self-Efficacy}

Learning model that has been directed to regenerate argumentation skills have been applied in the learning process, including the Argument Driven Inquiry (ADI) model, but the implementation still has weaknesses; 1) Student group ADI has not performed better than students in the control group test conceptual understanding of key chemistry concepts, but they show a better performance on the use of reasoning and evidence. 2) Students of the control group had completed 11 of laboratory experiments, while the student group ADI only completed six investigations, 3) exposure to the investigation have been less likely to result in the mastery of science concepts fewer student group ADI ${ }^{[43,44]}$.4) Students with low academic level in the group ADI were to have lower scores on a practice exam ${ }^{[46]}$. Needed more time allocation has been to implement a model of learning in the laboratory ADI ${ }^{[40]}$. Two phases of the ADI, namely the phase of peer review and report writing should have been done outside of school hours ${ }^{[40]}$. 5) Implementation of the model ADI has been proven to improve the quality of arguments, but do not have to change the attitude of student teachers to the teaching of science ${ }^{[41]}$, and 6) have facilitated individual skill argued orally through discussion and peer interactive discourse of argumentative writing is a difficult task to do without the direction of sustainable ${ }^{[45]}$.

Implementation of the argumentation skills in learning science has been in dire need of teachers/lecturers who are able to understand the process of argumentation and self-efficacy beliefs about the benefits of argumentation in science learning ${ }^{[65]}$. Self-efficacy beliefs is important because it has been able to affect cognition, motivation, affective processes and in the end that person's behavior ${ }^{[21,29,30]}$. During this selfefficacy is obtained through indirect learning, as the effects are carried over from the impact of the learning undertaken. That requires a learning model as a guide in designing and implementing learning that can improve argumentation skills and self-efficacy. In order to meet the demand learning model that can integrate argue skills and self-efficacy, then developed a different model with a model of learning that has been there, because the characteristics that will be achieved is different from other learning outcomes. Each learning models deliberately designed to teach specific learning outcomes that are relevant and specific learning model in question ${ }^{[66]}$. Learning model developed is designed primarily to develop the argumentation skills and self-efficacy chemistry student teachers.Learning models that have been developed to improve the weaknesses ADI models by reference to the source of self-efficacy. The development of this model is supported by the theoretical and empirical studies as well as observing the criteria of good learning model. Learning model that has been developed consists of six phases. Each phase of the learning model of equal importance in achieving the learning objectives designed so that the sixth phase related to each other. The first phase is to explain the objectives and identify chemistry issues. This phase is designed to be raised curiosity and interest of students to what will be studied and challenged to complete tasks proposed. Successes and failures can greatly affect a person's success, but sustained efforts towards a certain goal will help produce a "resilient sense of efficacy" ${ }^{[67]}$. The second phase is the argumentation skills based chemistry modeling graphic organizer. Students must understand the relationship between the questions, data, claims, warrants, backing and qualifications. For a graphic organizer that is designed to assist students in activities that argumentation. Graphic organizer has been able to provide space for any questions and steps associated with the process of argumentation ${ }^{[68]}$. Schunk, Hanson and Cox in Sewell and St George ${ }^{[69]}$ have shown that the use of peer models mastery and coping peer models are effective in improving student self-efficacy. Previous research has also shown that intervention in the form of modeling experience success and have a positive effect on selfefficacy physics student teachers to teach science through argumentation ${ }^{[21]}$. The third phase is the investigation of chemistry problems in small groups. The purpose of this phase is to give students the opportunity to learn how to design and conduct informative investigations, analyze the data and understand how science works. Science investigation activities can act as a catalyst for change in self-efficacy and student learning process ${ }^{[70]}$.

The fourth phase is the argument presented chemistry. This phase provides an environment in which students develop criticism, claims and their evidence in negotiations the whole class. The fifth phase is the transformation of the chemistry arguments in writing. The learning model is asking students to write because writing is an important aspect of scientific investigation. Writing improve personal construction of meaning to verbal symbols, which further increased the construction of scientific knowledge and the development of scientific literacy. Writing improve students' critical thinking skills and reasoning about the meaning of data ${ }^{[71]}$. Prat-Sala and Redford ${ }^{[29]}$ states that selfefficacy beliefs are strongly related to the ability to write an individual requires them to understand the components involved in the writing process. The sixth phase is to examine arguments based chemistry understanding and provide feedback. This phase is designed to encourage students to develop and use appropriate standards to determine what is the argumentation of quality. Lecturers should provide their students specific feedback on a regular basis with immediate in terms of their achievement, because it is an indication that they are making progress in their learning and can lead to their self-efficacy beliefs and ultimately improve academic achievement ${ }^{\text {[72]. Learning }}$ model developed is expected to be used to train and improve the argumentation skills and self-efficacy of students. Through argumentation skills in real life by applying knowledge of chemistry, students are expected to build understanding and more meaningful understanding of chemistry concepts as they form their own knowledge structure so that the chemistry concepts, is expected to increase self-efficacy students to enrich the learning experience and transfer knowledge. 


\section{Conclusion}

The innovative chemistry learning model as guidelines for faculty to design and implement learning that can improve and empowering potential of students through activities that argument can be used to teach the concept andself-efficacy of chemistry student. The chemistry innovative learning model is expected to be able to be an alternative solution to improve the argumentation skillsand self-efficacy chemistry teacher students. Suggestions for further research, this innovative learning chemistry model are merely theoretical, so it needs to be tested and implemented in the classroom to see the validity, practicality, and effectiveness.

\section{References}

[1] AGEPP (Asia Good ESD Practice Project). (2008). BukuPedomanPendidikanuntuk Pembangunan Berkelanjutan di Asia. Abe Osamu. Japan Council on the UN Decade of Education for Sustainable Development.

[2] Ngabekti, S. (2012). KonsepPendidikanuntuk Pembangunan Berkelanjutan: KasusPondokPesantren Modern Selamat Kendal. (Disertasi Doktortidakdipublikasikan). SekolahPascasarjanaUniversitas Gajah Mada. Yogyakarta.

[3] Redhana, I.W. (2015). "MenyiapkanLulusan FMIPA yang MenguasaiKeterampilan Abad XXI". Prosiding Seminar Nasional FMIPA Undiksha V Tahun 2015. (pp. 1-18). Denpasar.

[4] AACTE and P21. (2010). 21 $1^{\text {st }}$ Century Knowledge and Skills in Educator Preparation. American Association of Colleges of Teacher Education and the Partnership for 21st Century Skills (P21).

[5] Marttunena, M., Leena, L., Lia, L. and Kristine, L. (2005). "Skills as Prerequisites for Collaborative Learning among Finnish, French, and English Secondary School Students". Educational Research and Evaluation, 11 (4). 365-384.

[6] Osborne, J., Erduran, S., and Simon, S. (2004). "Enhancing The Quality Of Argumentation In School Science". Journal of Research in Science Teaching. 41(10). pp. 994-1020.

[7] Cross, D., Taasoobshirazi, G., Hendricks, S. and Hickey, D. (2008). “Argumentation: A Strategy for Improving Achievement and Revealing Scientific Identities”. International Journal of Science Education, 30 (68), 837-861.

[8] Sampson, V., and Clark, D.B. (2008). "Assessment of the Ways Students Generate Arguments in Science Education: Current Perspectives and Recommendations for Future Directions". Science Education, 2008, Wiley Periodicals Inc. 448-472.

[9] Jim'enez-Aleixandre M.P., and Erduran, Sibel. (2007). Argumentation in Science Education: An Overview. Argumentation in Science Education: Perspectives from Classroom-Based Research (pp 3-28). Springer Science + Business Media B.V.

[10] Jim'enez-Aleixander, M.P., Rodri'guez, A.B., and Duschl, R.A. (2000). "Doing the Lesson" or "Doing Science": Argument in High School Genetics". Science Education, John Wiley\&Sons Inc. 758-792.

[11] Kelly, G.J., and Takao, A.(2002). "Epistemic Levels in Argument: An Analysis of University Oceanography Students'Use of Evidence in Writing." Science education, 2002, Wiley Periodicals Inc. 314-342.

[12] Cavagnetto, A.R. (2010). "Argument to Foster Scientific Literacy A Review of Argument Interventions in K-12 Science Contexts". Review of Educational Reasearch, 80 (3), 336-371.

[13] Newton, P. E., Driver, R., and Osborne, J. (1999). "The Place of Argumentation in the Pedagogy of School Science". International Journal of Science Education, 21(5), 553-576.

[14] Erduran, S., Ozdem, Y. and Park, Jee-Young. (2015). "Research Trends on Argumentation in Science Education: A Journal Content Analysis from 1998-2014". International Journal of STEM Education, 2(5), 1-12.

[15] OECD. (2010). PISA 2009 Results: What Students Know and Can Do-Student Performance in Reading, Mathematics and Science; Volume I. http://dx.doi.org/10.1787/9789264091450-en.

[16] OECD. (2013). PISA 2012 Results: What Students Know and Can Do-Student Performance in Reading, Mathematics and Science, (Volume I). PISA. OECD Publishing. http://dx.doi.org/10.1787/9789264201118-en.

[17] Driver, R., Newton, P., and Osborne, J. (2000). "Establishing the Norms of Scientific Argumentation in Classrooms". Science Education, 84 (3), 287-312.

[18] Duschl, R. and Osborne, J. (2002). "Supporting and Promoting Argumentation Discourse in Science Education". Studies in Science Education, 38, 39-72.

[19] Kuhn, D. (2010). "Teaching and Learning Science as Argument". Science Education, 94 (5), 810-824.

[20] Simon, S., Erduran, S., and Osborne, J. (2006). "Learning to Teach Argumentation: Research and Development in the Science Classroom". International Journal of Science Education, 28 (2), 235-260.

[21] Ogan-Bekiroglu, F., and Aydeniz, M.(2013). "Enhancing Pre-service Physics Teachers' Perceived Self-efficacy of Argumentationbased Pedagogy through Modelling and Mastery Experiences". Eurasia Journal of Mathematics, Science \& Technology Education, 2013, 9(3), 233-245.

[22] Roshayanti, F. and Rustaman, N.Y. (2009). "ProfilSosiocultural Perspective dalamBerargumentasiMahasiswaCalon Guru BiologiPadaPerkuliahanFisiologiManusia". Proceedings The 3rd International Seminar on Science Education"Challenging Science Education in The Digital Era".ISBN: 978-602-8171-14-1.

[23] Pezaro, C., Wright, T., and Gilles, R. (2014). "Pre-service primary teachers' argumentation in socioscientificissues". Proceedings of the Frontiers in Mathematics and Science Education Research Conference. (pp. 58-69). Famagusta, North Cyprus.

[24] Aydeniz, M. and Ozdelik, Z. (2015). “Assessing Pre-Service Science Teachers' Understanding of Scientific Argumentation: What Do They Know About Argumentation After Four Years of College Science?”.Science Education International. 26(2). $217-239$.

[25] Acar, Ö., Patton, B. R., and White, A. L. (2015). "Prospective Secondary Science Teachers' Argumentation Skills and the Interaction of These Skills with Their Conceptual Knowledge". Australian Journal of Teacher Education, 40(9). 132-156.

[26] Supeno. (2014). "KemampuanBerargumentasillmiahMahasiswaCalon Guru Fisika". Prosiding Seminar NasionalPendidikanSainsTahun 2014:“Inovasi PendidikanSainsdalamMenyongsongPelaksanaanKurikulum 2013”. (pp. 405-410). Surabaya.

[27] Erika, F. (2016). "KemampuanBerargumentasiMahasiswaPendidikan Kimia FKIP UniversitasMulawarman". Prosiding Seminar NasionalPendidikanSainsTahun 2016:"Mengubah KaryaAkademikMenjadiKaryaBernilaiEkonomiTinggi”. (pp. 673-677). Surabaya.

[28] Sandoval, W.A. (2003). "Conceptual and Epistemic Aspects of Students'Scientific Explanations". The Journal Of The Learning Sciences, 12(1), 5-51.

[29] Prat-Sala, M., and Redford, P. (2012). "Writing essays: does self-efficacy matter? The relationship between self-efficacy in reading and in writing and undergraduate students' performance in essay writing”. Educational Psychology,32(1), 9-20.

[30] OECD. (2015). PISA 2015 Draft Questionnaire Framework. http://www.oecd.org/pisa/pisaproducts/PISA-2015-draftquestionnaire-framework.pdf. 
[31] Jerald, C.D. (2007). Believing and Achieving(Issue Brief). Washington, DC: Center for Comprehensive School Reform and Improvement.

[32] Kurbanoglu, N.I. and Akim, A. (2010). “The Relationships between University Students' Chemistry Laboratory Anxiety, Attitudes, and Self-Efficacy Beliefs". Australian Journal of Teacher Education, 35(8), 48-59.

[33] Tenaw, Y.A. (2013). "Relationship Between Self-Efficacy, Academic Achievement And Gender In Analytical Chemistry At DebreMarkos College Of Teacher Education". AJCE, 3(1), 3-28.

[34] Erözkan, A. (2014). "Analysis of Social Problem Solving and Social Self-efficacy in Prospective Teachers". Educational Sciences: Theory \& Practice, $14(2), 447-455$.

[35] Erözkan, A. (2013). "The Effect of Communication Skills and Interpersonal Problem Solving Skills on Social Self-Efficacy". Educational Sciences: Theory \& Practice, 13(2), Spring, 739-745.

[36] Sampson, V., Grooms, J., and Walker, J. (2011). "Argument-Driven Inquiry as a way to help students learn how to participate in scientific argumentation and craft written arguments: An exploratory study". Science Education, 95(2), 217-257.

[37] Walker, J. and Sampson, V. (2013a). "Learning to argue and arguing to learn in science: Argument-Driven Inquiry as a way to help undergraduate chemistry students learn how to construct arguments and engage in argumentation during a laboratory course". Journal ofResearch in Science Teaching, 50(50),561-596.

[38] Walker, J. and Sampson, V. (2013b). "Argument-Driven Inquiry: Using the Laboratory To Improve Undergraduates' Science Writing Skills through Meaningful Science Writing, Peer-Review, and Revision”. J. Chem. Educ. 90, 1269-1274.

[39] Sampson, V., and Walker, J.P. (2012). Argument-Driven Inquiry as a Way to Help Undergraduate Students Write to Learn by Learning to Write in Chemistry. International Journal of Science Education, 34(10), 1443-1485.

[40] Demircioglu, T. and Ucar, S. (2015). "Investigating the Effect of Argument Driven Inquiry in Laboratory Instruction". Educational Sciences: Theory \& Practice, 15 (1), 267-283.

[41] Demircioglu, T. and Ucar, S. (2012). "The effect of argument-driven inquiry on pre-service science teacher' attitudes and argumentation skills". Procedia-Social and Behavioral Sciences,46, 5035 - 5039.

[42] Grooms, J. (2011). "Using Argument-Driven Inquiry to Enhance Students' Argument Sophistication When Supporting a Stance in the Context of Socioscientific Issues". Electronic Theses, Treatises and Dissertations.Paper 3950.

[43] Walker, J., Sampson, V., Grooms, J., Anderson, B., and Zimmerman, C. (2010). Argument Driven Inquiry: An Instructional Model for Use in Undergraduate Chemistry Labs. In Paper Presented at The 2010 Annual International Conference of the National Association of Research in Science Teaching (NARST). Philadelphia, PA.

[44] Aydeniz, M., Pabuccu, A., Setin, P.S., and Kaya, E. (2012). “Argumentation and Students's Conceptual Understanding of Properties and Behaviors of Gases". International Journal of Science and Mathematics Education, 10, 1303-1324.

[45] Hasnunidah, N., Susilo, H., Irawati, M.H., and Sutomo, H. (2015). "Argument-Driven Inquiry with Scaffolding as the Development Strategies of Argumentation and Critical Thinking Skills of Students in Lampung, Indonesia". American Journal of Educational Research, 3(9), 1185-1192.

[46] Walker, J., Sampson, V., Southerland, S., and Enderle, P. J. (2016). "Using the Laboratory to Engage All Students in Science Practices". Chem. Educ. Res. Pract., 17, 1098-1113.

[47] Nuffield Practical Work for Learning: Argumentation. (2013a). "Argumentation and practical work - An introduction". Nuffield Foundation.

[48] Erduran, S., Ardac, D. and Yakmaci-Guzel, B. (2006). "Learning to Taech Argumentation: Case Studies of Pre-Service Secondary Science Teacher". Eurasia Journal of Mathematics, Science and Technology Education, 2 (2), 1-14.

[49] Van Eemeren, F.H., and Grootendorst, R. (2004). A Systematic Theory of Argumentation: The pragma-dialectical approach. Cambridge University Press. United States of America.

[50] Kelly, G.J. and Chen, C. (1999). "The Sound of Music: Constructing Science as Sociocultural Practices through Oral and Written Discourse". Journal Of Research In Science Teaching. 36 (8), 883-915.

[51] Sadler, T.D and Fowler, S.R. (2006). "A Threshold Model of Content Knowledge Transfer for Sosioscientific Argumentation". Science Education. 90 (6), 986-1004.

[52] Duschl, R.A. (2008). "Science Education in Three-Part Harmony: Balancing Conceptual, Epistemic, and Social Learning Goals". Review of Research in Education,32, 268-291.

[53] Moreno, R. (2010). Educational Psychology. John Wiley and Sons.

[54] Inch, S.E. and Warnick, B. (2006). Critical Thinking And Comunication, The Use of Reason in Argumen, Pearson Education.

[55] Wojdak, J.M. (2010). "An Attention-Grabbing Approach to Introducing Students to Argumentation in Science". Bioscience Communication, 15, 1-3.

[56] Hakyolu, H. and Ogan-Bekiroglu, F. (2011). "Assessment of Students' Science Knowledge Levels and Their Involvement with Argumentation". International Journal for Cross-Disciplinary Subjects in Education (IJCDSE), 2(1), 264-270.

[57] McDonald, C.V. (2014). "Preservice Primary Teachers' Written Arguments in a Socioscientific Argumentation Task". Electronic Journal of Science Education, 18(7).

[58] Bandura, A. (1977). "Self-Efficacy: Toward Unifying Theory of Behavioral Change". Psychological Review. 84(2), 191-215.

[59] Bandura A. (1997). Self-efficacy: the exercise of control. New York, NY: Freeman.

[60] Moos, D.C. and Azevedo, R. (2009). "Learning With Computer-Based Learning Environments: A Literature Review of Computer Self-Efficacy”. Review of Educational Research, 79 (2), 576-600.

[61] Jungert, T and Rosander, M. (2010). "Self-efficacy and strategies to influence the study environment". Teaching in Higher Education. (15), 6, 647-659.

[62] Keller, J.M. (1987). "Strategies for Stimulating the Motivation to Learn". Performance and Instruction, 26(8). 1-7.

[63] Erlich, R.J. (2011). Developing Self-Efficacy and Self-Regulated Learning in Academic Planning: Applying Social Cognitive Theory in Academic Advising to Assess Student Learning Outcomes. (Unpublished doctoral dissertation). Oregon State University.

[64] Temel, S. (2013). "The Effects of Problem-Based Learning on Self-Regulated Learning Skills and the Variables Predictive of These Skills". Mediterranean Journal of Social Sciences, 4(14). 297-302.

[65] Nuffield Practical Work for Learning: Argumentation. (2013b). "Argumentation -Research summary". Nutffield Foundation.

[66] Ibrahim, M. danSukartiningsih, W. (2014). Model Pembelajaran InovatifMelaluiPemaknaan. Unesa University Press.

[67] Gunning, A.M. and Mensah, F.M. (2011). "Preservice Elementary Teachers' Development of Self-Efficacy and Confidence to Teach Science: A Case Study". Journal of Science Teacher Education, 22, 171-185.

[68] Bulgren, J.A. and Ellis, J.D. (2012). Argumentation and Evaluation Intervention in Science Classes: Teaching and Learning with Toulmin. In M. S. Kwine (Eds.), Perspectives on Scientific Argumentation: Theory, Practice and Research (pp. 135-154). Springer Science+Business Media B.V.

[69] Sewell, A. and St George, A. (2000). "Developing Efficacy Beliefs in the Classroom”. Journal of Educational Enquiry. 1(2), 58-71. 
[70] Ketelhut, D.J. (2007). "The Impact of Student Self-efficacy on Scientific Inquiry Skills: An Exploratory Investigation in River City, a Multi-user Virtual Environment". Journal of Science Education and Technology, 16 (1), 99-111.

[71] Kingir, S. (2013). "Using Non-traditional Writing as a Tool in Learning Chemistry". Eurasia Journal of Mathematics, Science \& Technology Education, 9(2), 101-114.

[72] Haddoune, A.S. (2009). "Reflection on Students' Self-Efficacy Expectancies: Paving the Path to better Achievement in Higher Education". http://www.oecd.org/edu/imhe/43977414.pdf 